\title{
The Verbal Paradigm in the Generic Utterance
}

The last two chapters discussed the distribution and function of the verbal forms in two text types: the dialogue and the narrative. In the present chapter I will examine the verbal paradigm in the third text type, the generic utterance.

\subsection{Preliminaries}

Genericity is a mode of reference. As many have observed, the generic meaning is often not inherent in a particular lexical or a grammatical element; rather, it is a reading, an interpretation of the linguistic expression advanced by a certain context. ${ }^{1}$ The generic mode of reference may be applied to either an entity or a state of affairs. A generic entity is one referring to a concept or a kind, rather than a certain object or individual; a generic state of affairs is one referring to a fact or a certain order of things, rather than an event or episode. ${ }^{2}$

Generic reference is distinct from particular reference in that it indicates only an implicit relation to the deictic center of the text. In both dialogue and narrative the reference is established with respect to a particular entity, i.e., the speaking subject/first person narrator or the third person narrator (see above 4.2). Being a particular subject, the speaker/narrator endows a certain element with particularity by locating it in an exclusive relation with respect to himself. ${ }^{3}$ Consequently, this element is anchored in the situation of speech or narration and interpreted in relation to it. It is not the case that in assigning generic reference, the speaker does not have 'a particular referent in mind,

1 Hawkins, Definiteness, 214-217; Ter Meulen, Generic Information, 123; Krifka, Genericity, 8-9; Jacobsson, Notes on Genericity, 151; Shisha-Halevy, Topics, 403.

2 The notion of 'mere fact' or 'order of things' is contrasted with the notion of 'event' or 'episode' in that the latter has a temporal relevance; it addresses 'the tension between situations and changes-of-situations', see Fuchs, Deixis, 102.

3 That a linguistic expression obtains a referential value with respect to the speaking person was recognized by several linguists, cf. Benveniste, Subjectivity, 225, and Coseriu, Determinierung, 269, who says: Die Situierung schliesslich ist der Vorgang, in dem die fest bezeichneten Gegenstände 'situiert'werden, d.h. durch die sie mit den in die Rede einbezogenen 'Personen' verknüpft und durch die sie in Bezug zu den räumlich-zeitlichen Gegebenheiten der Rede gesetzt werden.

(C) MICHAL MARMORSTEIN, 2016 | DOI: 10.1163/9789004310483_012

This is an open access chapter distributed under the terms of the Creative Commons

Attribution-Noncommercial-Non-Derivative 3.o Unported (CC-BY-NC-ND) License 
or that he 'does not have a commitment to its (i.e. the referent's) existence within the relevant universe of discourse. ${ }^{4}$ Rather, the speaker does not locate the referent in an exclusive relation with respect to himself, and therefore the referent is not anchored in the situation of speech, nor dependent upon it for its interpretation.

The fact that generic utterances exhibit only an implicit relation to the speaking subject should not be confused with the notion of objectivity. Generic utterances are often described as 'eternal-truths' or 'law-like' statements, related to the higher level of 'types' rather than 'tokens', reflecting our conceptual organization of reality. ${ }^{5}$ Indeed, generic information is not concerned with the description of particular situations, but, as pointed out by Ter Meulen, 'its purpose is to classify such situations as being of a particular type. ${ }^{6}$ That being said, one should bear in mind that a generic utterance, like any other utterance, is also transmitted by a certain subject whose imprints, even if subtle, may still be discerned in the structure of the clause.

Generic utterances record human knowledge, experience, law or custom. Regardless of their length, they form self-sufficient textual units. I shall use the term generic clauses to refer to the morpho-syntactic realization of generic utterances. A set of generic clauses often constitutes an expository text or, with 'normative' generics (see below 11.4), a codex. Generic clauses can be found in generic speech-situations, e.g., proverbs collections, moral and wisdom literature, or scholarly writing. However, a generic clause can also be called into a particular speech-situation, to support the specific exchange of discourse. In these cases, the generic may precede the particular clause and serve as an exposition, or follow the particular clause and provide an explanation to it. The operator 'inna is often used as an explicit mark of these two inter-clausal semantic relations (see also above 9.2.2), as illustrated in the following examples:

(11.1) ya hanāh 'inna l-nāsa yamzaḥūna wa-yal'abūna wa-lā yu'āhad̄ūna bi-

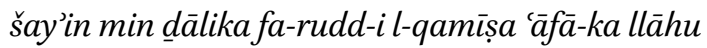

$O$ you, People jest and make fun and they are not reprehended for any of this, [so] hand back the gown, May God keep you in good health! (Buhalä, 63)

4 Hawkins, Definiteness, 215; Givón, Definiteness and Referentiality, 293-294.

5 Dahl, On Generics, 99-100; Kleiber, Phrases habituelles, 28-29.

6 Ter Meulen, Generic Information, 125. 
(11.2) lā tanzuranna 'ilà șig̀ar-ı̀ wa-du'f-ì fa-'inna l-'umūra laysat tağrī 'alā lquwwati wa-l-šiddati wa-l-dufi

Do not look at my smallness and weakness, for the matters are not guided by power, strength, [or] weakness. (Kalïla wa-Dimna 82)

The fact that generic reference may be applied to both a nominal-phrase and a verbal-phrase brings about four possible combinations within clauses whose predicate is a verbal form. Following the terminology suggested by Galmiche, these four types of clauses are listed in table 11.1 below. Notice that only when both the subject and the predicate are generically interpreted a generic clause is obtained: ${ }^{7}$

TABLE 11.1 Episodic, habitual, and generic clauses

\begin{tabular}{|c|c|c|c|}
\hline & & \multicolumn{2}{|c|}{ Verbal predicate } \\
\hline & & particular & generic \\
\hline \multirow{2}{*}{ Nominal subject } & particular & episodic clause & habitual clause \\
\hline & generic & episodic clause & generic clause \\
\hline
\end{tabular}

In the following, I will discuss the verbal forms which are found in main generic clauses and the functional oppositions between them (embedded generic clauses were discussed above in chapter 7 , see [7.11], [7.12], [7.23], [7.57], [7.66], [7.67], [7.88], [7.92], [7.93]). A brief presentation of the overall structure of generic clauses will precede the discussion. The properties of the generic nominal subject will not be dealt with. ${ }^{8}$

7 Galmiche, Phrases génériques, 23, includes in his classification one more type, the jugement générique which predicate an essential property of the kind. In terms of its grammatical characteristics, however, this type rests on a less solid definition, and therefore it is not included here. A similar combinatory approach to generic sentences is outlined in Mumm, Verbale Definitheit, 171-172.

8 For a detailed discussion of the theme in generic verbal clauses in Classical Arabic, see Marmorstein, Verbal Generics. 
Generic clauses are often introduced into discourse by formulas involving the verb qāla, e.g.: wa-qad qüla (Kalīla wa-Dimna, 69) 'It has been said', fa-yuqālu (Buhalä', 41) 'It is said', wa-qad kāna yuquàlu (Kalìla wa-Dimna, 66) on disait, wa$m \bar{a} z a \bar{a} l \bar{u}$ yaqūlūna (Buhalā', 39) 'They [= people] kept on saying'. Such formulas announce a generic clause; however, they do not form part of its internal structure.

Generic clauses may exhibit the structure of either the nominal clause or the verbal clause (see above 4.5), although the first option is far more common. The nominal pattern may be simply signaled by the placing of the subject ahead of the predicate, or it may take the marked form of an 'amma $\mathrm{fa}$ - 'as for ... so' clause, or be headed by the operator 'inna or one of its 'sisters', viz., lākinna 'but', lianna 'since' or 'anna 'that' (introducing the content clause of verbs such as $z a^{\prime} a m a$ 'to maintain', 'alima 'to know', and ra'ä 'to see, comprehend', see above $7.2)$.

Occasionally, generic clauses exhibit the pattern of the verbal clause. This pattern is triggered by the occurrence of the following operators and operations: (a) negation, interrogation, modification particles such as qad and focus particles such as 'innama preceding the verb; (b) emphasizing of a complement of the predicate, brought as such to the beginning of the clause, or emphasizing of the verbal lexeme itself; (c) impersonal verbs like yanbagi 'it is desirable' taking a content clause as their subject; and (d) passive verbs. An accumulation of these elements is also encountered (e.g. 'innamā yanbaji 'an).

\subsection{Indicative Verbal Forms in Generic Clauses}

In the grammatical literature, genericity is usually discussed in relation to nominal determination. However, genericity is also applied to verbal-phrases. In such cases, the generic mode of reference encodes a non-exclusive relation between the situation expressed by the verb and the subject engaged in discourse. In many languages the present tense is employed to signal this type of reference. This, however, cannot be simply explained away by the basic temporal denotation of this tense. The 'actual present' and the 'generic present' are not just distinct in their duration, exhibiting 'a gradual transition from what is more or less momentary to "eternal truths"', as Jespersen puts it, but rather they are distinct in their very nature. The 'actual present' is anchored in the situation of speech, it refers indeed to what is 'valid now', while the 'generic present' is in 
principle incompatible with the notion of 'now', always exclusive and relative with respect to a particular subject. ${ }^{9}$

The generic verb indicates either a static situation, with stative lexemes, or a dynamic situation, a disposition achieved by a frequentative, non-contingent repetition of an action. Frequentative repetition is one that has achieved the force of a law: it does not only refer to actual cases but also to possible and predictable ones. ${ }^{10}$ As defined by Kleiber, frequentative repetition, in contrast to mere iteration, does not take place in an interval of time, but applies for the whole interval of time referred to. ${ }^{11}$ Both generics and habituals denote a frequentative repetition, yet they are distinct from each other, since only in the latter case the interval of time is limited by the presence of a particular subject. ${ }^{12}$

In Classical Arabic, the verbal form yaf'alu is the regular, most common form of verb occurring in generic clauses. As opposed to fáala, yaf'alu is essentially non-eventive. It depicts an ongoing situation rather than a framed episode. As opposed to qadfa'ala, yaf'alu is temporally unbounded. This opposition clearly emerges in the following example:

\section{(11.3) fa-qad ğamáa hādāa l-ismu l-hamda wa-l-māla wa-smu l-buhliyağmáu l-māla wa-l-damma \\ And this noun (i.e. 'generous') has comprised praise and money, while the noun 'miserliness' comprises money and dispraise. (Buhalä', 91)}

In dialogue, the interval of time indicated by yaf'alu is delimited by the presence of a particular, spatiotemporally bounded person: either the first person, i.e., the subject engaged in discourse, or the second and third persons, determined with respect to him. This interval may be further specified by time-

Jespersen, Modern English, 4, 17-18. Kleiber, Phrases habituelles, 109-111, subscribing to the same view, explains the eternal validity of generic verbal sentences as produced by: (a) the neutrality of the present tense, (b) the stability of the predicate and (c) the durativity inherent in the generic noun-phrase. This, however, appears more like a description than an explanation of the generic sense. As a matter of fact, neutrality, stability, and durativity stem all from the lack of subjective anchoring.

10 Dahl, On Generics.

11 Kleiber, Phrases habituelles, 111-116.

12 In a similar fashion, Mumm, Verbale Definitheit, 172, finds the distinction between allgemeinen, ausserzeitlichen Sachverhalte and allgemeine Eigenschaften konkreter individueller Subjekte to relate only to the distinction between zeitgebundenem und zeitungebundenem Verbalhandlungsträger. 
adverbs. When yaf'alu is not a main verb but a predictive (dependent) form, it is temporally limited by the interval of time indicated in the matrix clause. In generic clauses, $y a f^{\prime} a l u$ does not refer to the situation of speech or is dependent on another verb, thus it is left indeterminate to the extent that it almost conveys the pure notion of the verbal lexeme. To put it in Guillaume's terms, yaf'alu in generic clauses reaches the end of maximal extension. ${ }^{13}$

The generic validity of $y a f^{\prime} a l u$ is diminished when a specific interval of time is indicated:

(11.4) wa-'ammā l-fursu fa-inna-hum kānū yủarrihūna bi-mulūki-him wahum l-yawma fi-mā 'álamu yu’arrihūna bi-'ahdi yazdağirda bni šahriyāra

And as for the Persians, they used to date according to [the reigns of] their kings, and today — as far as I know - they date according to the period of Yazdğard b. Šahriyār. (Tảrịn 1, 201)

The modifier qad occasionally precedes the generic yaf'alu. It serves as an explicit mark of the meaning of possible repetition implied by the generic yaf'alu. The modified qadyaf'alu always precedes the subject, thereby realizing the order of the verbal clause:

\section{(11.5) al-ğāhilu lā yakūnu munșifan wa-qad yakūnu l-ālimu mu'ānidan} The ignorant cannot be just whereas the learned may [well] be obstinate. ('Uyūn 2, 140)

Other operators which precede yaf'alu are qallama 'seldom' and rubba $(m \bar{a})$ 'many (a time)'. Like qad, these restrict the meaning of universal or extensive quantification, otherwise implied by the plain yaf'alu, and stress the notion of (high/low) frequency in which the verbal situation is likely to recur:

13 Extension, as defined first by Guillaume, Particularisation et generalisation, is the reference-potential of a lexeme, existing in the langue as a scale ranging between the two ends of particular and universal reference. In the transition to the parole a certain segment of this scale is realized by the operation of a determiner, such as the article in the case of a noun. The generic realization of a lexeme is therefore an approximation to the universal end of the scale, to the end of maximal extension. Wilmet, Contre la généricité, has further elaborated this notion to account not just for the domain of the nominal syntagm, termed by him extensité, but also for the domain of the predication, termed by him extensitude. 
(11.6) wa-qallamā tanğaḥu ḥilatu l-áğalati wa-l-irhāqi The hasty and excessive device seldom succeeds. (Kalìla wa-Dimna, 91)

(11.7) man-i staqalla bi-dā̉i-hì fa-lā yatadāwayanna fa-'inna-hū rubba yūrițu l-däa

He who cares little for his disease and does not treat himself, many [a time] transmits the disease. ('Uyūn 3, 296)

The modifier $l a$-is rarely conjoined with a generic $y a f^{\prime} a l u$. The form la-yaf'alu, as discussed above (9.2.3), occurs in the frame of inna clauses. The clausal pattern 'inna la-marks the predicative relation, the nexus, as focused:

(11.8) wa-mā ḥumqu l-ruba'i wallāhi 'inna-hū la-yağtanibu l-udawā’a wayatba'u 'umma-hū fì l-mar'à wa-yurāwihu bayna l-ațbäi wa-ya lamu 'anna ḥanina-hà ruġäun fa-'ayna ḥumqu-hu

And what is the stupidity of the rubac (i.e., a young camel born in the season called $r a b \bar{\imath})$ ? By God, it surely avoids uneasiness, follows its mother in the pasture, alternates between [its mother's] dugs and knows that its [mother's] yearning [sounds like] grumble, so where is its stupidity? (Hayawān 7,22 )

Focus, as is well known, marks the subjective stance of the speaker. At first sight this might seem contradictory to the notion of genericity. However, a generic utterance, though not anchored in a particular situation of speech, is not devoid of subjectivity. ${ }^{14}$ Subjectivity is explicitly marked in the clausal pattern 'inna laor when the operator 'innamā is employed. It is also marked formally in a clause whose predicate or one of its complements are emphasized and thus fronted to the beginning of the clause. The modal verbal forms, to be discussed below, are naturally colored with subjectivity; however, yaf'alu forms often have a shade of modal meaning as well (see below [11.10]-[11.11]). The difference between focus in particular and generic clauses is that in the first case the pragmatic motivation for the subjective expression is present and evident, while in the second case, due to the transferability of generic utterances (enabled by their non-anchoredness), this motivation is lost along the way.

14 Subjectivity and subjective anchoring are not overlapping terms: the first is much more wide and elusive: it applies not only to the deictic binding of the expression to the situation of discourse, but to any disclosing of the speaker's involvement or attitude marked formally in the structure of the clause, see above 4.2. 
Generic yaf'alu forms are nearly always negated by $l \bar{a}$. Only in rare occasions laysa is used and $m \bar{a}$ was encountered on only one occasion. The negated yaf'alu usually follows a definite subject and precedes an indefinite one:

(11.9) inna-nì la-kum ḍyfun wa-l-dayfu là yușāriúu rabba manzili-hì I am your guest and the guest does not fight with his host (lit. 'the lord of his house'). (Riwāyāt 1, 129)

(11.10) wa-lä yaqtulu mu'minun mu'minan fí käfirin

And a believer shall not kill another believer for the sake of an infidel. (Sira 1, 342)

However, in certain cases the negated yaf'alu also precedes the definite subject: (a) when the verb is in the passive, or (b) when the content negated is restricted by either 'illa 'except', hattā 'until', or mā l-daymūma 'mā of duration':

(11.11) maktūbun fì l-tawrāti là yựadu l-ḥadịtu marratayni

It is written in the Torah: The story is not to be repeated twice. ('Uyün $2,194)$

(11.12) fa-lā yub'idu llāhu 'illā man zalama

And God does not remove but the one who does wrong. (Buhalä, 150)

(11.13) lā ya'rifu l-rağulu hața'a mu'allimi-hì hattā ya'rifa l-ihtilāfa

The man is not aware of his teacher's mistake until he is acquainted with the disagreeing [opinion]. ('Uyün 2, 143)

(11.14) là yazālu l-mar'u 'āliman mā țalaba l-ilma

The man does not cease to be learned as long as he asks for lore. ('Uyün $2,134)$

Verbs introducing direct speech form a special class of clauses. They may be realized either in nominal clauses, specifying the source of the saying, or in verbal clauses, serving to announce the saying. The verb may take the form of either yaf'alu or fáala. The generic-episodic opposition between the two forms, even if not entirely forgotten, seems to be worn down to a large extant with these verbs:

\section{(11.15) wa-yaz'umu 'ahlu l-tawrāti}

And the people of the Torah maintain ... (Ta'rinh 1,190$)$ 
(11.16) fa-'ammà 'ahlu l-tawräti fa-'inna-hum yaz'umūna As for the people of the Torah, they maintain ... (Ta'rinh 1, 251)

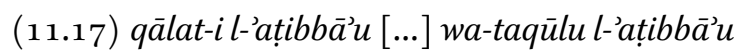
The physicians said $[\ldots]$ and the physicians say ... ('Uyūn 3, 302-304)

Besides conditional structures, the occurrence of fa'ala in generic clauses is rather restricted. The most obvious case in which fa'ala assumes a generic sense is in proverbs. The example 'anğaza hurrun mā wa'ada 'A free man fulfills what he promises' is one repeatedly quoted since de Sacy's grammar in every discussion on the generic use of fa'ala. Other such examples abound in proverb collections such as al-Maydānī's mağma'l-'amtāal, e.g.: 'arafa ḥumayqun ğamala-hū '[Even] a foolish man knows his camel', 'āda l-sahmu 'ilā l-naza'ati 'The arrow comes back to the shooters', taraka l-zabyu zilla-hū 'The gazelle has forsaken its shelter'.

Proverbs, as is well known, form a special kind of generic statements. In terms of their syntactic structure, proverbs, like verse, are allowed much latitude and flexibility, thus manifesting a great variety of patterns. In fact, what identifies a proverb as such is not necessarily a distinct syntactic structure (though typical structural features common to proverbs naturally exist), but rather its being aknowledged as a proverb. In other words, a proverbial statement is defined by its unambiguous generic reading, regardless of its syntactic structure. ${ }^{15}$ The generic interpretation of facala in proverbs is thus advanced by the given generic context, or by what may be described as the 'proverbization' of the clause. ${ }^{16}$

Apart from proverbs, facala seems to assume a generic sense in certain patterns of negation. With a generic subject, fa'ala negated by $m \bar{a}$, occasionally reinforced by qattu, refers not to the non-occurrence of an episode, but to the whole interval of time in which a certain occurrence did not take place. In a similar manner, the negated form lam yaf'al may also be used to indicate such a 'sweeping' negation. As mentioned above, negation triggers as a rule the order of the verbal clause:

15 As pointed out by Taylor, Proverb, 3 , it is 'an incommunicable quality', rather than a certain structural property, that 'tells us this sentence is proverbial and that one is not'.

16 What is meant here by 'proverbization' are the linguistic shaping and stabilization of the proverbial statement, as well as the extralinguistic process of its being aknowledged as such. 
(11.18) mā naqașa mālun qaț̣u min zakātin

Money never grew less through charity. (Buhalä, 50)

(11.19) mā warratatat-i l-'ābāu l-'abnā'a šay'an 'afḍala min-a l-'adabi

Fathers never bequeathed to their sons anything better than fine education. ('Uyūn 2, 136)

(11.20) țumma lam yūlad șabiyyun mahtūnun qațtu

Afterwards, never was a circumcised boy born. (Hayawān 7, 27)

(11.21) fa-lam tazal-i l-suhafầu tastahiffu l-'ulamà'a

The fools never ceased to scorn the wise people. (Kalïlawa-Dimna,120)

Another case in which a generic interpretation of fa'ala suggests itself is the following interrogative clause. In the contour of a rhetoric question, this statement implies that people always waste their money on ghee and honey:

(11.22) wa-hal 'afsada l-nāsu 'amwāla-hum 'illāfíl-samni wa-l-'asali

Did people [ever] lose their wealth but [through spending] on ghee and honey?! (Buhalä, 79)

In one more case fa'ala seems to assume a generic sense: this is when it is preceded by the operator rubbama 'many a time', or its subject is constructed with rubba 'many'. The operator rubba $(m \bar{a})$ does not indicate universal quantification. Nevertheless, rubba(mā) fa'ala conveys the implication that the occurrence which took place several (few/many) times in the past is bound to repeat itself again in the future, as illustrated in the examples below. Notice that in [11.24] fa'ala is followed by yaf'alu, the latter form is referential to the first, indicating a succeeding event:

(11.23) wa-'inna l-ṣaḡira rubbamā 'azuma

The small one many a time turned great. (Kalïla wa-Dimna, 71)

(11.24) wa-'inna l-malika l-hāazima rubbamā 'abj̇ạ̣a l-rağula wa-kariha-hū tumma yuqbilu 'alay-hi wa-yuqarribu-hü

The judicious king many a time hated a man and detested him and afterwards he would turn to him and bring him close. (Kalïla waDimna, 121) 
(11.25) 'inna-hū rubba mutaḥayyilin'awqa'at-hu ḥilatu-hū fı̀ šarrin Many a swindler was brought down to worse by his [own] deceit. (Katīla wa-Dimna, 116)

As pointed out above, the form yaf'alu serves to indicate an order of things, an unbounded situation, thus it is very suitable for generic utterances. The form fa'ala, by contrast, is essentially episodic and used to indicate framed situations, thus its use in generic clauses is limited. The generic reading of facala, to summarize the above discussion, is advanced by: (a) a generic contextual frame, such as a proverb; (b) a 'sweeping' negation, i.e., a negation valid for an entire interval of time (in this case, lam yaf'al may also be employed); (c) an interrogative carrying the implication of an experience never contradicted; or (d) the operator rubba $(m \bar{a})$ implying the reoccurring of past occurrences. As opposed to the 'universal' generalizations marked by yaf'alu, fa'ala is used in what may be described as 'existential' generalizations, i.e., generalizations that form a set of actual cases that create a certain commitment or expectation regarding the yet-to-occur cases. That is, while yaf'alu may well have a generic reference, fa'iala, as it appears, can only have a generic inference.

The participle is not often found in generic utterances. As mentioned earlier (5.2.1), the participle assumes a temporal value when it has deictic anchoring, i.e., when it is personally (hence spatiotemporally) bounded. By contrast to a particular participle, which refers to a temporally bounded state, a generic participle is temporally indeterminate; it serves to predicate an inherent property of an entity. Whether active or passive, the generic participle indicates a static aspect, as opposed to the dynamic, frequentative aspect indicated by the generic yaf'alu:

\section{(11.26) wa-l-mālu zāhirun näfíun mukarrimun li-'ahli-hī mu'izzun}

Money is bright, beneficial, endowing honor and esteem to those who own it. (Buhalä, 91)

(11.27) wa-l-zuğăğu 'abqā 'alā l-māi wa-l-turābi min-a l-dahabi l-ibrīzi wahuwa ma'a d̄àlika mașnū un wa-l-dahabu mahlūqun

Glass is more resistant to water and earth than pure gold, though it is artificial while gold is created [by God]. (Buhala $\vec{a}, 42)$ 


\subsection{Modal Verbal Forms in Generic Clauses}

Generic utterances exhibit not only the indicative forms, but also modal forms such as the imperative if'al, the prohibitive $l \bar{a}$ yaf'al and the energetic (la $)$ yaf'alanna. A modal form conveys the meaning of a prescriptive statement rather than a descriptive one. ${ }^{17}$ It serves to express a norm, an ideal, a desired order of things rather than an existing one. The second person, inherent in the imperative, is also very common with the other modal forms. Generic dictations and interdictions often stem from a hutba 'speech', once delivered in front of a particular audience and now transferred to the pages of history for the benefit of the succeeding generations. The following set of examples illustrates the use of modal forms in generic clauses:

(11.28) i'mal li-dunyā-ka 'amala man ya'išu 'abadan wa-'mal li-'āhirati-ka man yamūtu gadan

Do for your life in this world as one who lives forever and do for your life in the hereafter [as] one who dies tomorrow. (Buhalä', 154)

(11.29) lā yarǧuwanna 'abdun 'illā rabba-hū wa-lā yahăfanna 'illā danba-hū The servant of God should not ask [for anyone] but his lord and should not be afraid [from anything] but his sin. ('Uyūn 2, 135)

(11.30) là tahquiranna 'aduwwan wa-'in kāna haqüran da'îfan Do not despise an enemy, even if he is despised and weak. (Kalīla waDimna, 105)

(11.31) lā taṭlub taqwìma mā lā yastaqìmu wa-lā ta'dība mā lā yar'awì Do not try to fix what cannot be fixed and to enlighten what cannot see the light. (Kalīla wa-Dimna, 113)

\subsection{Summary}

In this chapter, I have dealt with a subset of generic utterances in Classical Arabic whose predicate is verbal. Generic reference was defined as the establishment of a non-exclusive relation between the linguistic expression and the

17 For the semantic distinction between descriptive and normative 'nomic' statements, see Dahl, On Generics, 101. 
subject engaged in discourse, providing its deictic center. It was shown that of the two finite indicative forms, the non-episodic yaf'alu displayed a much wider use than the episodic fa'ala. The latter assumed a generic sense (or implication) only in restricted syntactic environments where its episodic meaning was overridden. With normative generic clauses, the modal forms if'al, la $y a f^{\prime} a l$ and $(l \bar{a})$ yaf'alanna were attested. These served to express a desired order of things rather than to describe an existing one. Generic clauses were attested in the corpus either as self-contained textual units or as units integrated in dialogues or commentary parts of the text, supporting as such the particular exchange of discourse. 